\title{
Genetic variability and relative drought tolerance in interspecific progenies of Brassica juncea
}

\author{
V.V. Singh ${ }^{1}$, P.K.Rai ${ }^{1}$, S.A. Siddiqui ${ }^{1^{*}}$, V. Verma ${ }^{1}$ and Rajbir Yadav ${ }^{2}$ \\ ${ }^{1}$ Directorate of Rapeseed-Mustard Research, Sewar, Bharatpur (Rajasthan), India- 321303 \\ ${ }^{2}$ Division of Plant Breeding and Genetics, IARI, New Delhi, India \\ ABSTRACT
}

\begin{abstract}
Genetic variability plays an important role in plant breeding because hybrids between lines of diverse origin generally display a greater heterosis than those between closely related parents. Segregating progenies of interspecific crosses PCR-7/BPKR-13, RH-819/MCP-03, RH819/BPKR-13 and Varuna/BPKR-13 were maintained till $F_{7}$ generation through selfing. The relative drought tolerance of each progeny was quantified with respect to seed yield through Drought Susceptibility Index (DSI). The progenies were reported fertile at every generation $\left(F_{1}\right.$ to $F_{6}$ ) and fertility ranged from $85 \%$ to $98 \%$. The overall mean performance of progenies was comparatively higher in irrigated environment for days to $50 \%$ flowering, days to maturity, fruiting zone length, main shoot length, siliquae on main shoot, siliquae per plant, 1000 seed weight, seed yield per plant and protein content. Drought Susceptibility Index (DSI) was calculated for each genotype as a criterion of drought tolerance. The lowest value indicates the highest level of drought tolerance and vice-versa. The values of DSI ranged from $-0.139(07-547)$ to $1.316(07-$ 827) (Table-2). The genotypes $07-547,07-515$ and $07-510$ had lower DSI values $(<$ or $\sim 0.00)$, thus rated as drought tolerant. The progenies could be distinguished from each other by means of a combination of fragments which is repeatedly present in one progeny and absent in the other. However, out of 472 scored band, about $83 \%$ were polymorphic.
\end{abstract}

Keywords: Drought, genetic, Breeding, Hybrid and Polymorphic

\section{INTRODUCTION}

Indian mustard (Brassica juncea L.) is an important rabi oil seed crop and occupies a prime position due to its high oil content (37-42\%). In spite of all the efforts made over past few decades, the productivity has remained almost constant. This may be due to lack of high yielding genotypes with stable performance over the environment. Lack of genetic variability for some important yield components, even in the world germplasms collection, may be attributed to this. Ethiopian mustard (B. carinata A. Braun) is the oldest cultivated oilseed crops (Simmonds, 1979). Interspecific hybridization can easily be forced in the family brassicaceae where gene flow is very limited under natural conditions (Sandhu and Gupta, 2000). The level of genetic diversity performance has been proposed as a predictor of $F_{1}$ performance and heterosis (karkoo, et al. 2000). Genetic variability plays an important role in plant breeding because hybrids between lines of diverse origin generally display a greater heterosis than those between closely related parents (Syed, et al. 1956). In India, Brassica is mostly grown under arid and semi-arid environment therefore, could serve model crop. Adverse environmental factors, of which water scarcity represents the most severe constraint to agriculture, account for about 70 percent of potential yield loses worldwide. Further, rapeseed mustard group of crops are grown on conserved moisture received from monsoon rains. Drought conditions occur ubiquitously during the growing season and have a profound negative effect on rapeseedmustard productivity. This also necessitates screening and development of drought tolerance genotypes. Introgressions of desirable gene complexes form other species such as $B$. carinata has been suggested to further diversify the existing variability in mustard. A series of experiments were performed to synthesize the drought tolerant breeding material. Identification and phylogenetic relationship among and within the species can successfully be accomplished through RAPD markers (Ren et al. 1995). Now, it is the time to develop varieties which can tolerate water stress to increase yield and area under oilseed crops. The present paper provides information on nature of genetic variability for yield and yield components under normal and drought condition in interspecific progenies of $B$. juncea. The information derived from the study will help in breeding Brassica for drought tolerance. 
Agric. Biol. J. N. Am., 2011, 2(1): 34-41

\section{MATERIALS AND METHODS}

The present investigation was initiated in 2000-2001 and parental lines were raised during rabi 2001. Pedigree bulk method was carried out and evaluation to row progenies was followed in filial generation during subsequent years. Emasculation was done in the evening time. Emasculated pistils were covered by parchment paper bag and pollinated with pollen grains collected from freshly dehisced anther. $F_{1}$ progeny was raised in next year and morphological observations were recorded. Male fertility at $F_{7}$ stage was checked by anther squashed method using $2 \%$ acetoglycerocarmine and data were recorded under fluorescent microscope (Siddiqui et al. 2007; Rai et al. 2010). Segregating progenies of interspecific crosses PCR-7/BPKR-13, RH-819/MCP-03, RH819/BPKR-13 and Varuna/BPKR-13 were maintained till $F_{6}$ generation through selfing. Progenies at this stage consisted $B$. juncea type, $B$. carinata type and exact intermediate type. Therefore, rigorous selection on the basis of plant type was practiced. Thus, a total of $95 \mathrm{~B}$. juncea type and $46 \mathrm{~B}$. carinata type progenies were incorporated in this study. The $F_{7}$ generation raised during rabi, 2007-2008 in two separate experiments, each having continuous water deficit and irrigated field in augmented randomized complete block design. In each experiment, field was divided into five blocks having four checks. Drought experiments were kept unirrigated throughout the crop season. The each plot was having two rows of $4 \mathrm{~m}$ length with $30 \mathrm{~cm} \times 10 \mathrm{~cm}$ spacing. Ten plant were randomly selected from each plot to record the data on primary branches per plant, fruiting zone length, main shoot length, number of siliquae on main shoot, number of siliquae per plant, seed yield per plant, 1000 seed weight, oil and protein content. Reproductive and maturity stage were recorded on plot basis and analysis of variance was performed (Fedrer, 1956). The data was subjected to estimate the variability, heritability and genetic advance for seed yield and contributing traits. The simple correlation studies were carried out to establish the relationship among the seed yield and its component traits in rain fed as well as irrigated condition. The relative drought tolerance of each progeny was quantified with respect to seed yield through Drought Susceptibility Index (DSI) (Fischer and Maurer. 1978). The progenies selected on the basis of DSI and mean performance under drought condition were grown in replicated trials in a targeted environment during rabi 2008-09 for molecular analysis.

Molecular analysis:
DNA isolation: Total genomic DNA was extracted using the CTAB method (Dellaporta et al., 1983). $3 \mathrm{~g}$ of leaf tissue were collected and transported on ice, grounded to fine powder using liquid nitrogen, 100 $\mathrm{mg}$ of PVP (polyvinylpyrrolidone) together and transferred to $15 \mathrm{ml}$ extraction buffer containing $2 \%$ w/v CTAB, $4 \mathrm{M} \mathrm{NaCl}, 20 \mathrm{mM}$ EDTA, $0.1 \% \quad \beta-$ mercaptoethanol, $100 \mathrm{mM}$ Tris $\mathrm{pH} 8.0$ preheated to $65^{\circ} \mathrm{C}$ for $1 \mathrm{hr}$ with occasional shaking. The homogenate was cooled to room temperature and extracted with $15 \mathrm{ml}$ of chloroform: isoamyl alcohol (24:1), centrifuged at $12000 \mathrm{rpm}$ for $15 \mathrm{~min}$ at $20^{\circ} \mathrm{C}$. The clear aqueous phase was separated. $5 \mathrm{ml}$ of $5 \mathrm{M}$ $\mathrm{NaCl}$ and $10 \mathrm{ml}$ isopropanol were added to this and stored overnight at $4^{\circ} \mathrm{C}$. This was again centrifuged at $12000 \mathrm{rpm}$ at $20^{\circ} \mathrm{C}$ for $15 \mathrm{~min}$ and the supernatant was decanted retaining the pellet. The pellet was air dried and dissolved in $500 \mu \mathrm{l}$ of T.E. and left for 10 minutes. The solution was transferred in 1.5 eppendrof tube. $500 \mu \mathrm{l} \mathrm{T.E.} \mathrm{was} \mathrm{added} \mathrm{in} \mathrm{centrifuge}$ tube to dissolve remaining traces of DNA and left for 10 minutes. The solution was transferred in eppendrof tube to get total $1 \mathrm{ml}$ of DNA. For removing RNA, $5 \mu$ l RNase was added per $\mathrm{ml}$ of DNA and incubated for 1 hour at $37^{\circ} \mathrm{C} .1 \mathrm{ml}$ DNA was divided into two eppendrof tube containing 500 $\mu$ lof DNA. 250 $\mu \mathrm{l}$ phenol and $250 \mu \mathrm{l}$ chloroform was added, mixed gently and centrifuged at $12000 \mathrm{rpm}$ for 15 minutes at room temperature .The supernatant was isolated and equal volume of chloroform, was added, mixed gently and centrifuged at $12000 \mathrm{rpm}$ at room temperature. The supernatant was isolated and 1/10 vol. of sodium acetate (3M) and 2.5 vol. of chilled absolute alcohol, was added, mixed gently and keept for overnight at $20^{\circ} \mathrm{C}$. It was centrifuged at $10000 \mathrm{rpm}$ at $4^{\circ} \mathrm{C}$ for 20 minutes. The supernatant was decanted and the pellet was retained. The pellet was washed twice with the $70 \%$ alcohol and air dried. The pellet was

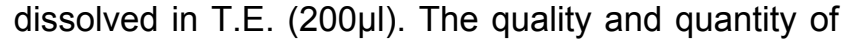
isolated genomic DNA were estimated by UV Spectrophotometer at $\left(\mathrm{A}_{260} / \mathrm{A}_{280}\right.$ absorbance $)$ as well as $0.8 \%$ argose gel electrophoresis.

RAPD analysis. Polymerase chain reactions was carried out for RAPD amplification in $25 \mu$ reaction mixture containing $5 \mu \mathrm{l}$ (50ng) template DNA, $13.5 \mu \mathrm{l}$ miliQ water, $2.0 \mu \mathrm{l}(0.8 \mathrm{x}) \quad 10 \mathrm{X}$ buffer, $2 \mu \mathrm{l}(0.8 \mathrm{mM})$ $\mathrm{Mgcl}_{2}, 1.2 \mu \mathrm{l}$ dNTPs, $1.0 \mu \mathrm{l}$ primer and $1 \mathrm{U}$ Taq DNA polymerase (Welsh and McClelland 1990). The amplification reaction was carried out in thermo cycler (master cycler- eppendorf) with following profiles: $94{ }^{\circ} \mathrm{C}$ for $5 \mathrm{~min},\left(94{ }^{\circ} \mathrm{C}\right.$ for $1 \mathrm{~min}, 37^{\circ} \mathrm{C}$ for 1 min and $72{ }^{\circ} \mathrm{C}$ for 2 min.) $\times 40$ cycles and $72{ }^{\circ} \mathrm{C}$ for $10 \mathrm{~min}$ for final elongation. The RAPD products were 
screened on $1.6 \%$ agarose gel. (Welsh and McClelland 1990).

\section{RESULT AND DISCUSSION}

Genetic Variability: The progenies were reported fertile at every generation $\left(F_{1}\right.$ to $\left.F_{6}\right)$ and fertility ranged from $85 \%$ to $98 \%$ (Fig.1). Due to high degree of pollen fertility, no difficulty was observed for seed formation through selfing (inbreeding). Analysis of variance showed that the progenies differed significantly for most of the characters except days to $50 \%$ flowering, primary branches per plant and oil content in irrigated environments whereas, under drought conditions significant differences was observed for days to $50 \%$ flowering, fruiting zone length, siliquae per plant, 1000 seed weight, seed yield per plant, oil and protein content. This indicated the existence of sufficient variability for these traits and response to selection may be expected in the breeding program me. The overall mean performance of progenies was comparatively higher in irrigated environment for days to $50 \%$ flowering, days to maturity, fruiting zone length, main shoot length, siliquae on main shoot, siliquae per plant, 1000 seed weight, seed yield per plant and protein content. Drought appeared to have reduced the overall mean performance of these traits by 10.19 , $27.6,28.89,18.24,33.17,60.46,19.10,68.76$ and 2.47 percent, respectively. For other traits i.e. primary branches per plant and oil content, mean performance was slightly higher in drought environment. The reduction in mean performance of progenies under drought situations for most of the traits may be ascribed to decreased translocation of assimilates and growth substances, impairing nitrogen metabolism, loss of turgidity and consequently reduced sink size (Kumawat et al 1997). The more or less similar observations were made by Singh and Choudhary (2003) and Chauhan et al (2007) in B. juncea where they reported up to $60 \%$ yield reductions under rainfed environments.

The variances of various characters were compared on the basis of coefficient of variation. It was observed that seed yield per plant followed by siliquae on main shoot in irrigated environment and oil content followed by 1000 seed weight in rain fed condition exhibited comparatively higher estimates of genotypic as well as phenotypic coefficient of variation (Table-1). It indicated that simple selection for these characters might be advantageous in particular condition. These results are in agreement with earlier report of Singh et al. (2007). The estimates of heritability in present investigation were of higher magnitude $(>50 \%)$ for all the characters with significant variability in both the conditions. Similar variability was observed by Singh et al. (2009).

The genetic advance was highest for oil content (\%) followed by thousand seed weight, siliquae per plant and seed yield per plant under rainfed conditions whereas, seed yield per plant followed by protein content (\%), siliquae on main shoot and siliquae per plant showed higher estimates of genetic advance under irrigated conditions. These findings indicate that there is good scope for development of genotypes having high oil content, increased seed weight and more number of siliquae per plant which would perform better in water stress conditions. Similarly, for irrigated conditions there is enough scope for development of promising genotypes having high protein content $(\%)$, more number of siliquae on main shoot and siliquae per plant. High heritability values accompanied with high genetic advance were observed for oil content (\%) and seed yield per plant under rainfed and irrigated conditions, respectively. Similar reports of high heritability with high genetic advance for these characters were made by Patel et al. (2006). This indicates that selection will be more effective for these characters as compared to others.

Seed yield per plant showed positive and significant correlation with number of siliquae per plant in rainfed $\left(r=0.356^{* *}\right)$ as well as irrigated $\left(.289^{*}\right)$ condition. Therefore, high yielding genotypes can be developed with more number of siliquae per plant for efficient use of scarce water resource as well as to respond favorably to input rich conditions. The results of present investigation are in accordance with Shalini et al (2000).

Drought Susceptibility Index (DSI) was calculated for each genotype as a criterion of drought tolerance. The lowest value indicates the highest level of drought tolerance and vice-versa. The values of DSI ranged from $-0.139(07-547)$ to $1.316(07-827)$ (Table-2). The genotypes 07-547, 07-515 and 07-510 had lower DSI values ( $<$ or $\sim 0.00$ ), thus rated as drought tolerant. Total 52 genotypes were found moderately drought tolerant $(>0.0-1.0)$ and 40 genotypes were ranked as moderately susceptible (>1.0-1.5) (Table 3). Clarke et al. (1984) opined that selection for yield under dry condition should alone be more productive avenue for improvement of drought resistance until more rapid and effective screening procedures could be developed. As DSI is a ratio, a genotype could have lower value of this index even when its mean seed yield under drought condition is significantly lower than better performing genotype (s). 
Agric. Biol. J. N. Am., 2011, 2(1): 34-41

Table-1: Estimates of Mean, Range, GCV, PCV, Heritability (bs) and Genetic advance for seed yield and its components in inter-specific progenies of Indian mustard under drought and irrigated conditions.

\begin{tabular}{|c|c|c|c|c|c|c|c|c|c|c|c|c|c|}
\hline \multirow[t]{2}{*}{ S.N. } & \multirow[t]{2}{*}{ Characters } & \multicolumn{6}{|c|}{ Drought condition } & \multicolumn{6}{|c|}{ Irrigated condition } \\
\hline & & Mean & Range & GCV & PCV & $\mathbf{h}^{2}$ & GA & Mean & Range & GCV & PCV & $h^{2}$ & GA \\
\hline 1. & Days to $50 \%$ flowering & 49.7 & $39.6-67.1$ & 7.4 & 9.4 & 62.7 & 11.9 & 55.3 & $40.7-67.7$ & * & * & * & * \\
\hline 2. & Days to maturity & 96.6 & $89.4-100.9$ & * & * & * & * & 133.5 & $100-142$ & 2.8 & 3.0 & 73.4 & 4.6 \\
\hline 3. & Primary branches/ plant & 5.9 & $3.8-8.4$ & * & * & * & * & 5.5 & $4.2-8.2$ & * & * & * & * \\
\hline 4. & Fruiting zone length $(\mathrm{cm})$ & 47.7 & $22.6-86.9$ & 14.6 & 17.3 & 71.7 & 25.3 & 67.1 & $39.8-87.3$ & 10.5 & 13.5 & 60.7 & 16.8 \\
\hline 5. & Main shoot length $(\mathrm{cm})$ & 37.2 & $16.2-54.9$ & * & * & * & * & 45.5 & $28.1-71.9$ & 13.6 & 16.2 & 70.5 & 23.5 \\
\hline 6. & Siliquae on main shoot & 22.5 & $15.4-41.2$ & * & * & * & * & 33.6 & $12.2-67.9$ & 22.4 & 23.2 & 92.9 & 44.5 \\
\hline 7. & Siliquae per plant & 73.6 & $10.5-144.5$ & 16.4 & 21.6 & 57.9 & 25.7 & 186.3 & $77.4-324.6$ & 20.6 & 25.8 & 64.1 & 34.1 \\
\hline 8. & Thousand seed weight (g) & 3.4 & $1.3-5.3$ & 23.6 & 29.6 & 63.6 & 38.5 & 4.2 & $4-7.2$ & 16.3 & 20.4 & 64.0 & 26.9 \\
\hline 9. & Seed yield per plant (g) & 3.3 & $1.3-8.3$ & 14.9 & 17.7 & 70.3 & 25.6 & 10.6 & $3.9-28.8$ & 44.6 & 46.6 & 91.6 & 88.0 \\
\hline 10. & Oil content (\%) & 42.2 & $38.3-44.5$ & 34.7 & 39.9 & 75.5 & 61.7 & * & * & * & * & * & * \\
\hline 11. & Protein content (\%) & 19.7 & $17.3-22.5$ & 2.6 & 2.87 & 80.3 & 4.7 & 20.2 & $18.4-28.3$ & 4.58 & 5.08 & 81.1 & 85.5 \\
\hline
\end{tabular}

* Mean sum squares were non-significant for these characters; hence genetic parameters were not calculated. 
Agric. Biol. J. N. Am., 2011, 2(1): 34-41

Table-2: $Y_{D}$ (Seed yield (g) under drought condition), $Y_{P}$ (Seed yield (g) under normal irrigated condition) and DSI (Drought susceptibility index) values of inter-specific progenies of Indian mustard

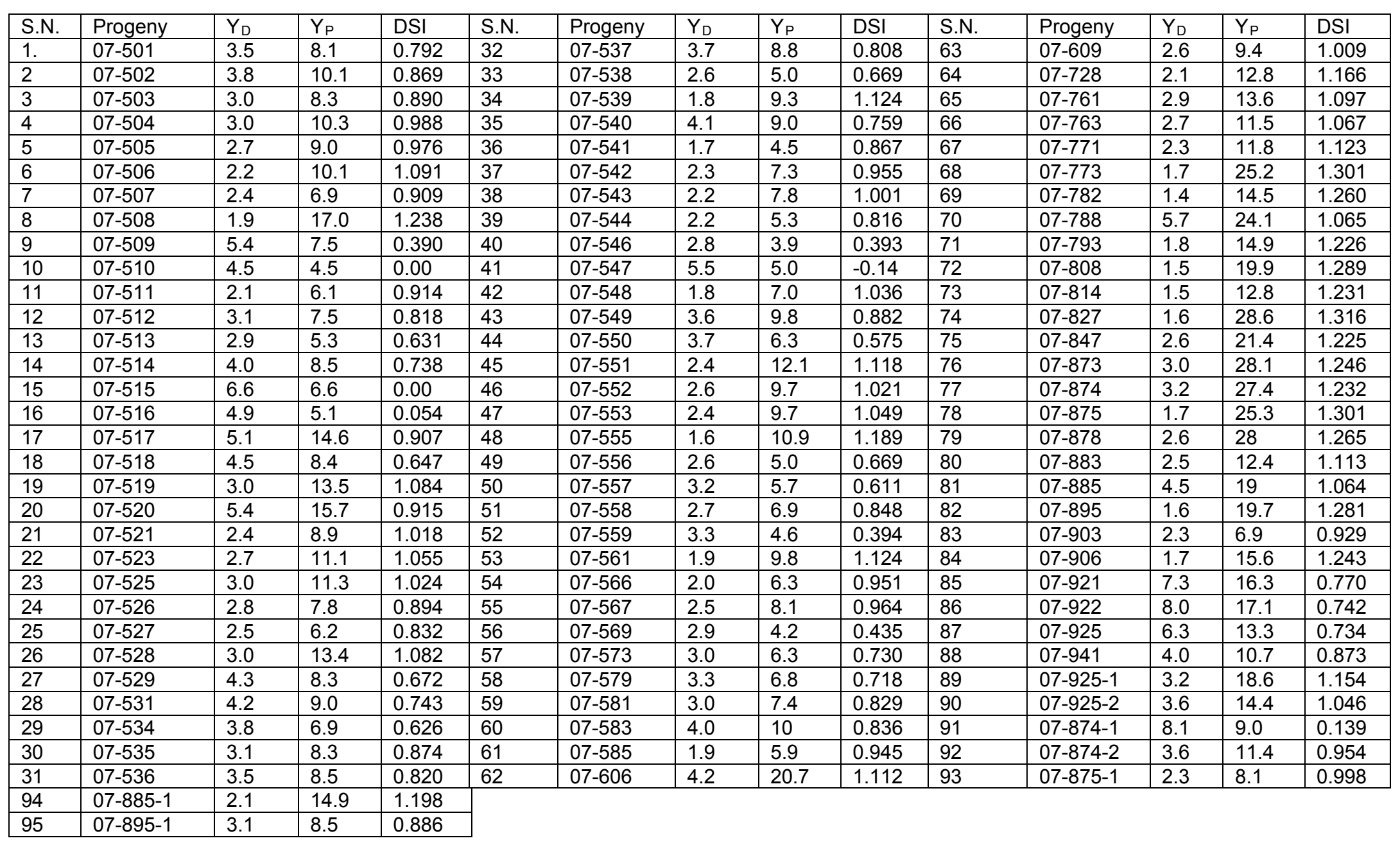


Table 3. Classification of advanced lines of Brassica juncea on the basis of DSI

\begin{tabular}{|c|c|c|}
\hline DSI value & Reaction & Genotype (s) \\
\hline$<0.0$ & Drought tolerant & $07-547,07-515$ and $07-510$ \\
\hline$>0.0-1.0$ & Moderately tolerant & $\begin{array}{l}07-501,07-502,07-503,07-504,07-505,07-507,07-509,07- \\
511,07-512,07-513,07-514,516,07-517,07-518,07-520,07- \\
520,07-526,07-527,07-529,07-531,07-534,07-535,07-536, \\
07-537,07-538,07-540,07-541,07-542,07-544,07-546,07- \\
549,07-550,07-556,07-557,07-558,07-559,07-566,07-567, \\
07-569,07-573,07-579,07-581,07-583,07-585,07-903,07- \\
921,07-922,07-922,07-925,07-941,07-872-1,07-874-2,07- \\
875-1,07-895-1\end{array}$ \\
\hline$>1.0-1.5$ & Moderately susceptible & $\begin{array}{l}07-508,07-519,07-521,07-523,07-525,07-528,07-539,07- \\
543,07-548,07-551,07-552,07-553,07-555,07-561,07-606, \\
07-609,07-728,07-761,07-763,07-771,07-773,07-782,07- \\
788,07-793,07-808,07-814,07-827,07-847,07-873,07-874 \text {, } \\
07-875,07-878,07-883,07-885,07-895,07-906,07-925-1,07- \\
925-2,07-885-1\end{array}$ \\
\hline$>1.5$ & Susceptible & --- \\
\hline
\end{tabular}
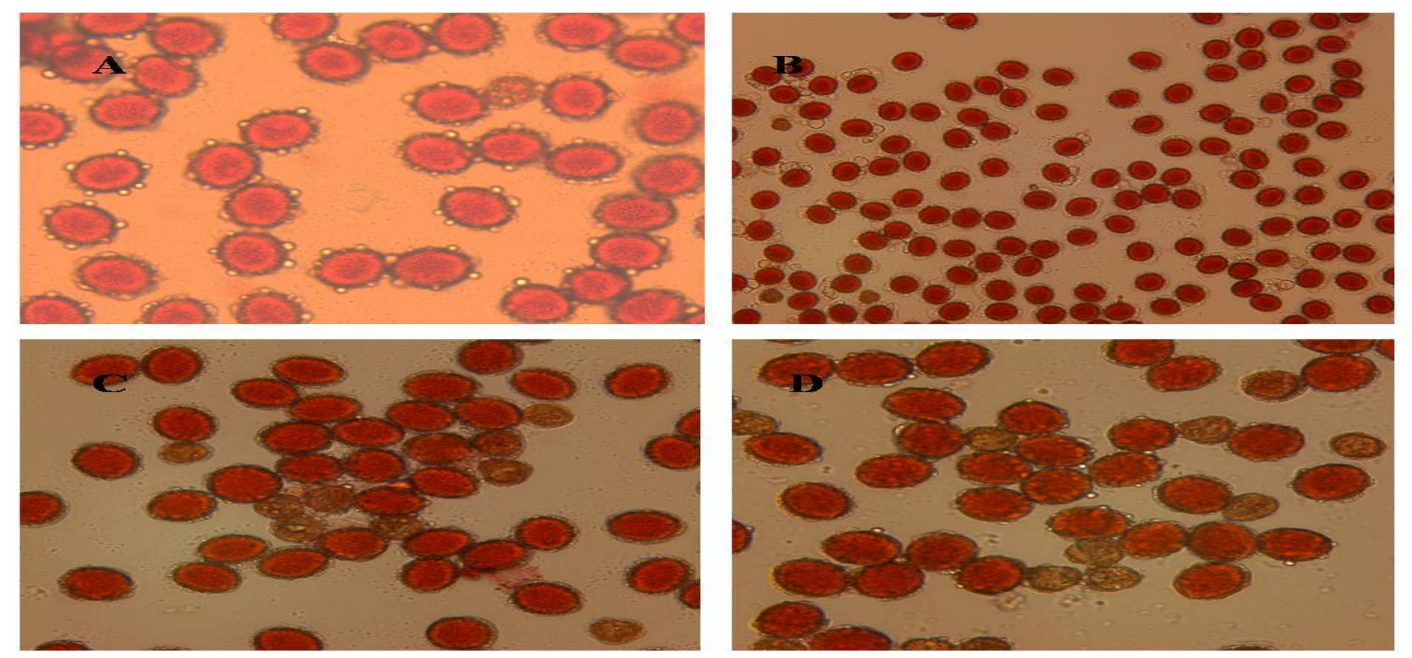

Fig.1.Pollen fertility A= B.juncea, B. carinata and C\&d= progenies

Therefore, genotypes in the present investigation were selected on the basis of high mean seed yield along with lower DSI value. Singh and Choudhary (2003) and Chauhan et al (2007) used DSI values and seed yield under drought conditions as a selection criterion in Indian mustard. Hence, progenies 07-547, 07-515, 07-509, 07-874-1, 07-922, 07-921 and 07-925 were found most promising and may be utilized in selection/ hybridization programme for yield improvement under drought condition.
RAPD fingerprinting for variability: Genetically variable drought tolerant lines, characterized on the basis of DSI and mean performance at $F_{7}$ stage, were validated using RAPD analysis in the next generation. Fifty five primers of arbitrary sequences were screened for their ability to produce polymorphic amplicons to which 42, giving reproducible and distinct polymorphic patterns, were selected. A total of 472 RAPD products were scored using these primers. The size of bands ranged from 550 to 2100 base pairs similar to the previously reported range in 
Brassica germplasm (Rabbani et al., 1998; Cartea et al., 2005). However, out of 472 scored band, about $83 \%$ were polymorphic which is in accordance to Cartea et al., (2005). The progenies could be distinguished from each other by means of a combination of fragments which is repeatedly present in one progeny and absent in the other (Fig. 2). The probable reason of higher average scorable and polymorphic bands can be attributed to the primers used in present investigation consisting $60-70 \%$ GC content. Considerable genetic diversity between European and Chinese oilseed rape using RAPD markers have been found (Demeke, et al. 1992).

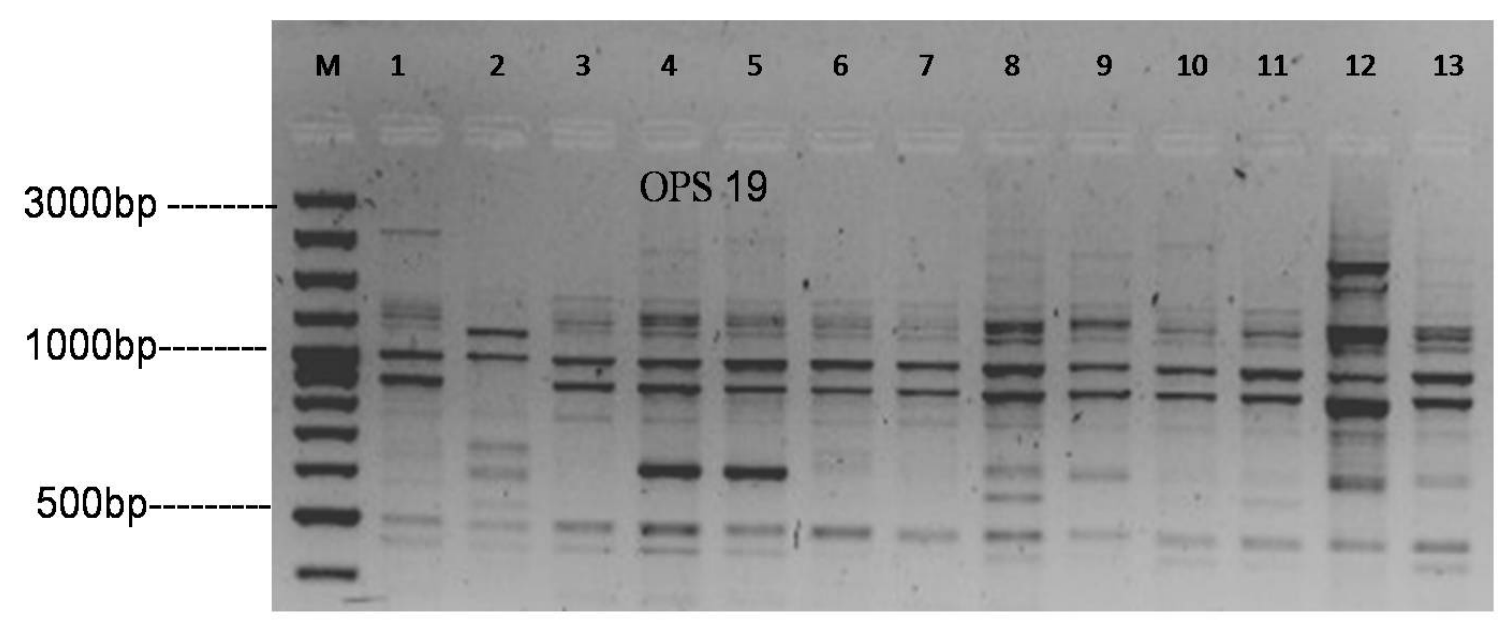

Fig. 2. $M=$ marker, $1=B$. juncea, (cv Varruna), 2 to $11 \& 13$ progenies and $12=B$. carinata

\section{REFERENCES}

Cartea ME, Soengas P, Picoaga A, Ordas A (2005) Relationships among Brassica napus (L). germplasm from Spain and great Britain as determined by RAPD markers. Genet Resour Crop Evol 52: 655-662.

Chauhan, J. S., Tyagi, M.K., Kumar, A., Nashaat N.I., Singh, M, Singh N.B., Jakhar M.L. and Welham S.J. 2007. Drought effects on yield and its components in Indian mustard (Brassica juncea L.) . Plant Breed. 126 (4): 399-402.

Clarke J., Townley-Smith T.F., McCaalg T.N. and Green D.M. 1984. Growth analysis of spring wheat cultivars of varying drought resistance. Crop Sci., 56:603-626.

Dellaporta, S.L., J. Wood, and J.B. Hicks.1983. A plant DNA minipreparation: Version II. Plant Mol. Biol. Rpt. 1:19-21.

Fedrer, W. T. 1956. Augmented Design. Hawain planters. Record 20: 191-207.

Fischer R.A. and Maurer R.1978. Drought resistance in spring wheat cultivars. 1. Grain yield responses. Australian J. Agril. Res., 29: 897-91.

Karkoo, S.K., L.N. Jinda, and R. D. satija. 2000. Genetic determination of seed yield through its components in
Indian mustard (B. juncea L.). Crop. Improv. 27 (3): 247-249

Kumawat, B. L. Sharma D. D. and Jat, S. C. 1997. Effect of Brassinosteroid on yield and yield attributing characteristics under water deficit stress condition in mustard (B. juncea L.). Ann. Biol. 13, 91-93.

Patel J.M., Patel K.M., Patel C.J. and Prajapati K.P. 2006. Genetic parameter and inter relationship analysis in Indian mustard (Brassica juncea L.): J. Oilseed Res. 23 (2): 159-160.

Rabbani MA, Iwabuchi A, Murakami Y, Suzuki T, Takayanagi K (1998) Genetic diversity in mustard (Brassica juncea L.) germplasm from Pakistan as determined by RAPDs. Euphytica 103: 235-242

Rai, P. K., S.A. Siddiqui, P. Goyal, V.V. Singh, and Pankaj Sharma. 2010. Pollen viability test of wild Brassica species and allied genera of the family Brassicaceae. Sarson Nwes. 13(2): 8.

Ren J, McFerson JR, Li R, Kresovich S, Lamboy WF (1995) Identities and relationships among Chinese vegetable brassicas as determined by random amplified polymorphic DNA markers. J. Amer. Soc. Hort Sci 120: 548-555 
Sandhu, S. K. and V. P. gupta. 2000. Interspecific hybridization among digenomic species of Brassica. Crop. Improv. 27 (1) : 195-197.

Shalini T.S., Sheriff, R.A., Kulkarni, R.S. and Venkataramana, P. (2000). Correlation and path analysis of Indian mustard germplasm. Crop Research Hissar. 1 (2): 226-229

Siddiqui, S.A., Sinha, P. and Kausal, P. 2007. Pollenn pistil interaction in interploidal and interspecific crosses in pearl millet. Rang. Mgmt and Aroforestry. 28 (2): 377379

Simonds, N. W. 1879. Princple of Crop Improvement, Pp. 541-548. Longman, England.

Singh, S.P. and Choudhary, A.K. 2003. Selection criteria for drought tolerance in Indian mustard (Brassica juncea L). Indian J. Genet. 63, 263-264.
Singh K.H. Mahawar R.K. and Kumar, A. (2007). Relationship between floral and agronomic traits in Indian mustard (Brassica juncea). 12 ${ }^{\text {th }}$ International Rapeseed Congress, Sustainable development in cruciferous oilseed crop production Wuhan (China). Sci. Press. USA Inc: 53.

Singh, V.V., Singh, Sudheer, Verma, Vandana, Meena, S.S. and Kumar, Arvind (2009). Genetic variability for seedling traits in In dian mustard under moisture stress conditions. Indian J. Plant Genet. Resour. 22(1): 4649.

Syed, S. A., A. Ali and K. Rehman. 1994. Improvement of rapeseed for agronomic and quality characters through induced mutation and hybridization. IAEA-TECDOC781, viena, 25-35.

Welsh, J. and McClelland, M. 1990. Fingerprinting genome using PCR with arbitrary primers. Nucleic Acid Res. 18: $7213-7218$. 